ADR Ultrasound (Tempe, Arizona) supplied the ultrasound equipment.

\footnotetext{
References

1 de Crespigny L C, Robinson $\mathbf{H}$ P, Murton L J, O'Herlihy C. Real-time scanning of the neonatal brain. Aust Paediatr J 1981 ; 17 : 78-82.

2 Lipscomb A P, Reynolds E O R, Blackwell R J, et al. Pneumothorax and cerebral haemorrhage in preterm infants. Lancet 1981 ; i: 414-6.

3 Leech R W, Kohnen P. Subependymal and intraventricular hemorrhages in the newborn. Am J Pathol 1974; 77: 465-75.

4 Tsiantos A, Victorin L, Relier J P, et al. Intracranial hemorrhage in the prematurely born infant: timing of clots and evaluation of clinical signs and symptoms. J Pediatr 1974; 85: 854-9.

5 Emerson $\mathbf{P}$, Fujimua $\mathrm{M}$, Howat $\mathrm{P}$, et al. Timing of intraventricular haemorrhage. Arch Dis Child 1977; 52: 183-7.
}

6 Lee B C P, Grassi A E, Schechner S, Auld P A M. Neonatal intraventricular hemorrhage: a serial computed tomography study. J Comput Assist Tomogr 1979; 3: 483-90.

7 Bejar R, Curbelo V, Coen R W, Leopold G, James H, Gluck L. Diagnosis and follow-up of intraventricular and intracerebral hemorrhages by ultrasound studies of infant's brain through the fontanelles and sutures. Pediatrics 1980; 66: 661-73.

8 Levene M I, Wigglesworth J S, Dubowitz V. Cerebral structure and intraventricular haemorrhage in the neonate: a real-time ultrasound study. Arch Dis Child 1981 ; 56: 416-24.

Correspondence to Dr L Ch de Crespigny, University of Melbourne, Department of Obstetrics and Gynaecology, Parkville, Victoria 3052, Australia.

Received 9 October 1981

\title{
Normal values for mature and immature neutrophils in very preterm babies
}

\author{
B W LLOYD AND A OTO \\ Department of Paediatrics and Neonatal Medicine, Hammersmith Hospital, London
}

SUMMARY Serial leucocyte counts were made on 24 babies of less than 33 weeks' gestation during the first 5 days of life. The values for mature neutrophils show two important differences from those obtained by previous workers studying term babies, in that the counts were much lower on the first day of life and showed a wider range of values at all ages. In contrast, immature neutrophil counts, expressed either as absolute values or as a proportion of the total neutrophil count (the I/T ratio), were similar to those found in previous studies and had a considerably narrower range.

Neutrophil counts are widely used to help diagnose infection in newborn babies. ${ }^{1-4}$ Published reference ranges have been largely constructed using data from term or fairly mature preterm babies. ${ }^{2} 56$ It has been suggested ${ }^{1257}$ that the neutrophil counts of preterm babies differ from those of term babies, casting doubt on the usefulness of these ranges when dealing with the very immature. Previous work on preterm babies has been with fairly mature infants ${ }^{15}$ (M Xanthou and E Hey, 1981, personal communications), so we set out to determine the range of mature and immature neutrophil counts in healthy babies of not more than 32 weeks' gestation.

\section{Patients and methods}

Twenty-four babies admitted to the neonatal intensive care unit at Hammersmith Hospital between June 1979 and August 1980 were studied with their parents' written consent and the approval of the hospital's ethical committee. All were 32 weeks' gestation or less according to their mothers' dates, and gestational assessment by the method of Dubowitz et al. ${ }^{8}$ Mean gestational age was 30.4 weeks (range 26-32) and mean birthweight $1510 \mathrm{~g}$ (range 900-1900).

Certain conditions were fulfilled to ensure that the infants could reasonably be considered healthy. There were 3 babies born after prolonged rupture of membranes and 8 with very mild and short-lived respiratory distress who had no clinical or laboratory evidence of infection.

Blood was taken from each baby at 1, 12, $24,48,72,96$, and 120 hours, although specimens were not obtained at every age from all. A total of 124 specimens was taken from 24 babies using capillary blood from the heel; $0.2 \mathrm{ml}$ of blood was taken into a tube containing $0.3 \mathrm{mg}$ of dipotassium EDTA. A total leucocyte count was performed using a Coulter counter. A blood film was stained using a standard May Grunwald (Giemsa) 
Table Values for mature and immature neutrophils and $I / T$ ratios in the first 5 days of life

\begin{tabular}{|c|c|c|c|c|c|c|}
\hline \multirow[t]{2}{*}{$\begin{array}{l}\text { Age } \\
\text { (hours) }\end{array}$} & \multicolumn{2}{|c|}{$\begin{array}{l}\text { Mature neutrophils } \\
\left(\times 10^{9} / l\right)\end{array}$} & \multicolumn{2}{|c|}{$\begin{array}{l}\text { Immature } \\
\text { neutrophils } \\
\left(\times 10^{9} / l\right)\end{array}$} & \multicolumn{2}{|l|}{$I / T$ ratio } \\
\hline & $\begin{array}{l}\text { Median } \\
\text { (range) }\end{array}$ & Mean & $\begin{array}{l}\text { Median } \\
\text { (range) }\end{array}$ & Mean & $\begin{array}{l}\text { Median } \\
\text { (range) }\end{array}$ & Mean \\
\hline$(n=10)$ & $\begin{array}{c}4 \cdot 64 \\
(2 \cdot 20-8 \cdot 18)\end{array}$ & $4 \cdot 57$ & $\begin{array}{c}0.11 \\
(0-1 \cdot 5)\end{array}$ & $0 \cdot 30$ & $\begin{array}{c}0.04 \\
(0-0.35)\end{array}$ & 0.09 \\
\hline $12(n=17)$ & $\begin{array}{c}6 \cdot 80 \\
(4 \cdot 0-22 \cdot 48)\end{array}$ & $8 \cdot 61$ & $\begin{array}{c}0.27 \\
(0-1 \cdot 6)\end{array}$ & 0.48 & $\begin{array}{c}0.04 \\
(0-0.21)\end{array}$ & 0.06 \\
\hline $24(n=17)$ & $\begin{array}{c}5 \cdot 60 \\
(2 \cdot 61-21 \cdot 20)\end{array}$ & $7 \cdot 64$ & $\begin{array}{c}0 \cdot 14 \\
(0-3 \cdot 66)\end{array}$ & 0.47 & $\begin{array}{c}0.03 \\
(0-0.17)\end{array}$ & 0.05 \\
\hline $48 \quad(n=20)$ & $\begin{array}{c}4 \cdot 98 \\
(1 \cdot 02-14 \cdot 43)\end{array}$ & $6 \cdot 24$ & $\begin{array}{c}0 \cdot 13 \\
(0-2 \cdot 15)\end{array}$ & 0.44 & $\begin{array}{c}0.02 \\
(0-0.17)\end{array}$ & 0.05 \\
\hline $72(n=22)$ & $\begin{array}{c}3 \cdot 19 \\
(1 \cdot 28-13 \cdot 94)\end{array}$ & $4 \cdot 63$ & $\begin{array}{c}0 \cdot 16 \\
(0-2 \cdot 42)\end{array}$ & 0.38 & $\begin{array}{c}0.03 \\
(0-0.25)\end{array}$ & 0.05 \\
\hline $96(n=21)$ & $\begin{array}{c}3 \cdot 44 \\
(1 \cdot 37-16 \cdot 56)\end{array}$ & $5 \cdot 33$ & $\begin{array}{c}0 \cdot 23 \\
(0-3 \cdot 95)\end{array}$ & 0.45 & $\begin{array}{c}0.05 \\
(0-0.37)\end{array}$ & 0.07 \\
\hline $120(n=17)$ & $\begin{array}{c}3 \cdot 46 \\
(1 \cdot 27-15 \cdot 00)\end{array}$ & $4 \cdot 98$ & $\begin{array}{c}0.25 \\
(0-2 \cdot 89)\end{array}$ & 0.44 & $\begin{array}{c}0.05 \\
(0-0.21)\end{array}$ & 0.07 \\
\hline
\end{tabular}

method. A differential count was performed on 100 leucocytes. A band cell was defined as a neutrophil in which the width of the narrowest segment of the nucleus is not less than one-third of the broadest segment. ${ }^{3}$

\section{Results}

Mature neutrophils. There was a wide range of values at each age particularly on the first day of life (Table). The values are not normally distributed; a few high values skew the mean upwards, so that at each age, except at one hour, the median is lower than the mean.

The median mature neutrophil count rises from $4 \cdot 64 \times 10^{9} / 1$ (range $2 \cdot 20-8 \cdot 18$ ) at one hour to a peak at 12 hours of $8.61 \times 10^{9} / 1$ (range 4.00 $22 \cdot 48$ ) and levels out at $3 \cdot 19 \times 10^{9} / 1$ (range $1 \cdot 28$ $13.94)$ by 72 hours. The values obtained from the 8 babies with mild respiratory distress lay evenly within the range of the other 16 babies.

Immature neutrophils. All band cells and cells less mature than band cells were classed together as immature neutrophils. The Table shows the results obtained at each age. There is no peak at about 12 hours comparable with that seen with the mature neutrophils. All but 15 of the 124 values were less than $1.0 \times 10^{9} / 1$.

The proportion of immature (I) to total (T) neutrophils - the I/T ratio-was also calculated for each blood count. The values obtained are shown in the Table. Only 13 counts had an $\mathrm{I} / \mathrm{T}$ ratio exceeding $0 \cdot 14$, of which only 5 exceeded $0 \cdot 2$.

\section{Discussion}

Our study is thought to be the first on healthy babies of such immaturity. Our results show broad similarities to those obtained from term babies in the studies mentioned above, ${ }^{256}$ but there are two important differences.

The peak in mature neutrophil values seen at 12 hours was considerably lower in our babies than that shown by other workers with term infants. ${ }^{1256}$ Akenzua's median at about $13.5 \times 10^{9} / 1$ is nearly double ours. Xanthou found a mean of $13.0 \times 10^{9} / 1$, although when she studied 14 preterm babies of considerably greater gestation than ours (M Xanthou, 1981, personal communication), the mean was very similar to ours at about $8.0 \times 10^{9} / 1$. Manroe found that at 12 hours $90 \%$ of her counts were within the range of $8.0-14.4 \times 10^{9} / 1 ; 70 \%$ of our babies had values below this lower limit.

After age 48 hours our median and mean values are close to the values obtained by others, ${ }^{256}$ but the range of neutrophil counts at each age is much wider in our babies. ${ }^{56}$ At every age from 12 hours, at least $30 \%$ of our babies had counts outside both Xanthou's and Manroe's ranges. Out of a total of 124 counts, 63 were outside Xanthou's range and 64 were outside that of Manroe; that is just over half of our counts are abnormal when compared with these ranges. In the first 48 hours most of these 'abnormal' values were below these two ranges, thereafter more were above them.

These findings cast considerable doubt on the widespread practice of comparing mature neutrophil counts obtained from preterm babies with reference standards based largely on data from term babies. Furthermore, their value depends on the experience of the technicians performing them.

In contrast, our values for immature neutrophils are not greatly different from those obtained by others. ${ }^{256}$ Several workers ${ }^{236}$ have suggested that the immature neutrophil count, either as an absolute value or expressed as the proportion of the total neutrophil count (the $I / T$ ratio), is of more help in the diagnosis of infection than is the mature neutrophil count. Our results, showing a considerably narrower range of normal for both immature neutrophils and $\mathrm{I} / \mathrm{T}$ ratios, support this idea.

We thank Stephen Coleman, Karen Grimett, and Arlene Levine for performing the differential counts, and Dr Pamela A Davies for helpful advice.

\section{References}

1 Gregory J, Hey E. Blood neutrophil response to bacterial infection in the first month of life. Arch Dis Child 1972 47: 747-53.

2 Akenzua G I, Hui Y T, Milner R, Zipursky A. Neutrophil and band counts in the diagnosis of neonatal infections. Pediatrics 1974; 54: 38-42. 
3 Zipursky A, Palko J, Milner R, Akenzua G I. The hematology of bacterial infections in premature infants. Pediatrics 1976; 57: 839-53.

4 Manroe B L, Rosenfeld C R, Weinberg A G, Browne R. The differential leukocyte count in the assessment and outcome of early onset neonatal group B streptococcal disease. J Pediatr 1977; 91 : 632-7.

5 Xanthou M. Leucocyte blood picture in healthy full term and premature babies during neonatal period. Arch Dis Child 1970; 45: 242-9.

6 Manroe B L, Weinberg A G, Rosenfeld C R, Browne R. The neonatal blood count in health and disease. I. Reference values for neutrophilic cells. J Pediatr 1979; 95: 89-98.
7 Coulombel L, Dehan M, Tchernia G, Hill C, Vial M. The number of polymorphonuclear leukocytes in relation to gestational age in the newborn. Acta Paediatr Scand 1979; 68: 709-11.

8 Dubowitz L M S, Dubowitz V, Goldberg C. Clinical assessment of gestational age in the newborn infant. J Pediatr 1970; 77: 1-10.

Correspondence to Dr B W Lloyd, Department of Paediatrics, New Cross Hospital. Wolverhampton WV10 OQP.

Received 17 November 1981

\title{
Oral converting enzyme inhibitor in malignant hypertension
}

\author{
WILLIAM GRISWOLD, RICHARD MCNEAL, DAN O'CONNOR, VIVIAN REZNIK, AND \\ STANLEY MENDOZA
}

Department of Pediatrics, University of California, San Diego, USA

SUMMARY Malignant hypertension, which developed in a 9-year-old boy after an episode of haemolytic uraemic syndrome, could not be controlled with antihypertensive agents. However, treatment with oral converting enzyme inhibitor (captopril) was effective in controlling the blood pressure and it averted bilateral nephrectomy. No adverse effects from the drug were noted.

Captopril (SQ 14225), an orally active inhibitor of angiotensin converting enzyme, has been used for the control of hypertension in adults. The following case shows the striking effectiveness of captopril in a child with malignant, high renin, drug-resistant hypertension.

\section{Case report}

This 9-year-old boy had been in good health until December 1977 when he developed haemolytic uraemic syndrome. In the hospital, the patient was anuric for $\mathbf{1 7}$ days and required peritoneal dialysis. As urine output resumed the blood pressure increased to $150 / 100 \mathrm{mmHg}$ requiring antihypertensive therapy. The patient was discharged after one month with a serum creatinine concentration of $1.6 \mathrm{mg} / 100$ $\mathrm{ml}(142 \mu \mathrm{mol} / \mathrm{l})$.

However one month later blood pressure rose to $150 / 110 \mathrm{mmHg}$ and the patient was readmitted with papilloedema, plasma urea $29 \mathrm{mmol} / \mathrm{l}$, and creatinine $4.4 \mathrm{mg} / 100 \mathrm{ml}(392 \mu \mathrm{mol} / \mathrm{l})$. Despite treatment the blood pressure was poorly controlled and serum creatinine levels remained high. Urinary vanillylmandelic acid was normal. Intravenous pyelogram and technetium renal scan showed decreased renal function but were otherwise normal. Peripheral venous renin was greatly increased at over $100 \mathrm{ng} / \mathrm{ml}$ per hour (normal 0-5). Renal biopsy showed evidence of nephrosclerosis with severe endothelial proliferation in the arterioles. Bilateral selective renal angiograms showed loss of corticomedullary junction and interlobular arteries suggesting glomerular disease. Renin was 81.9 in the right renal vein and $111 \mathrm{ng} / \mathrm{ml}$ per hour in the left.

His subsequent course was difficult, complicated by persistent hypertension despite treatment with various combinations of the following; propranolol $480 \mathrm{mg} /$ day $(26 \mathrm{mg} / \mathrm{kg}$ per day), hydralazine 400 $\mathrm{mg} /$ day (22 $\mathrm{mg} / \mathrm{kg}$ per day), prazosin $12 \mathrm{mg} /$ day $(0.6 \mathrm{mg} / \mathrm{kg}$ per day), methyldopa $1500 \mathrm{mg} /$ day $(82 \mathrm{mg} / \mathrm{kg}$ per day), clonidine $0.8 \mathrm{mg} /$ day $(0.04$ $\mathrm{mg} / \mathrm{kg}$ per day), minoxidil $40 \mathrm{mg} /$ day $(2.2 \mathrm{mg} / \mathrm{kg}$ per day), guanethidine $100 \mathrm{mg} /$ day $(5.5 \mathrm{mg} / \mathrm{kg}$ per day), and frusemide $400 \mathrm{mg} /$ day $(22 \mathrm{mg} / \mathrm{kg}$ per day). Heart size was persistently enlarged on chest $x$-ray film; echocardiogram showed left ventricular hypertrophy and pericardial effusion. Weight decreased to $18 \cdot 2 \mathrm{~kg}$. He was depressed and anorectic. There were 2 episodes of hypertensive encephalopathy. He underwent pericardiectomy for treatment of persistent effusion, probably due to minoxidil, in September 1978.

In late December 1978, permission to use captopril for this patient was obtained from Squibb via a humanitarian protocol. Other antihypertensives were 